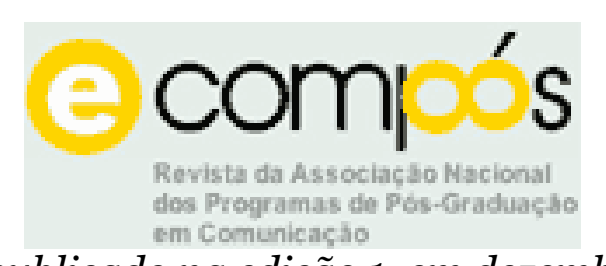

Este artigo foi publicado na edição 1, em dezembro de 2004, da revista eletrônica e-compós: http://www.compos.org.br/e-compos

\title{
UM ESTUDO DE RECEPÇÃO SOBRE AS TELE-CONSULTAS MÉDICAS
}

\author{
L.Graciela Natansohn ${ }^{1}$ \\ Faculdade de Tecnologia e Ciências-FTC/Salvador-Ba
}

\begin{abstract}
Resumo: Apresentamos resultados de uma pesquisa de recepção de programas de televisão onde médicos respondem a consultas do público, mediante a análise do contrato de leitura (Verón, 1985) dos programas. Analisamos as representações articuladas pelos dois programas - que versam sobre a saúde reprodutiva das mulheres - focalizando no ciclo menstrual e seus transtornos para, depois, analisar e comparar as estratégias discursivas propostas pelas emissões com as estratégias de consumo, recepção e usos dos programas, realizados por um setor da audiência. Pretendemos refletir e analisar teórica e metodologicamente, sobre como se estabelecem vínculos entre as múltiplas ofertas de consumo elaboradas pela televisão e as leituras, interpretações, apropriações e consumos efetivamente realizados pelos receptores.
\end{abstract}

Palavras-chave: recepção; televisão; gênero.

Resumen: Presentamos resultados de una investigación sobre la recepción de programas de televisión donde médicos responden a consultas del público, mediante el análisis del contrato de lectura (Verón, 1985) de esos programas. Analizamos las representaciones articuladas por los dos programas (que tratan de la salud reproductiva de las mujeres) centrándonos en el ciclo menstrual y sus transtornos para, después, analizar y comparar las estrategias discursivas propuestas por las emisiones com las estrategais de consumo, recepción y usos de los programas realizados por un sector de la audiencia. Pretendemos reflexionar teórica y metodologicamente, sobre como se establecen vínculos entre las múltiples ofertas de consumo elaboradas por la televisión y las lecturas, interpretaciones, apropiaciones y consumos realizados por los receptores.

Palabras clave: Recepción; televisión; género.

Abstract: This paper presents the results of research, based on Verón's (1985) reading contract, into reception of two television programs in which physicians respond to viewer questions. Representations present in both programs - which focus on women's reproductive health - are analysed, focusing on the menstrual cycle and its disturbances and then comparing the programs' discursive strategies with a part of the audience's strategies for their consumption, reception and use. Theoretical and methodological reflections follow, on how to establish links between television's multiple offerings and the actual readings, interpretations, appropriation and consumtion by the audience.

Keywords: reception - television - genre

\footnotetext{
${ }^{1}$ L. Graciela Natansohn é doutora em Comunicação pela Universidade Federal da Bahia (Brasil). Realiza pesquisa sobre recepção de televisão, saúde e gênero e leciona no curso de Comunicação da Faculdade de Tecnologia e Ciências-FTC- Salvador. E-mail: graci71@terra.com.br
} 
Resumée: Nous présentons ici les résultats d'une recherche menée sur la réception de programmes de télévision où des médecins repondent aux questions du public. Ladite étude est basée sur le modèle d'analyse du contract de lecture des émissions (Verón, 1985). Nous avons analysé des représentations articulées par deux émissions de télévision - qui $\mathrm{s}^{\prime}$ attachent au thème de la santé reproductrice des femmes - : dans un premier temps, nous nous sommes intéressés aux questions concernant le cycle menstruel et ses troubles, et dans un deuxième temps, nous avons procédé à l'étude et à la comparaison des stratégies discursives proposées par les émissions avec les stratégies de consommation, de reception d'usage des programmes télévisuels par une parcelle du public. Cette étude a pour but de réfléchir et d'analyser, au plan théorique et méthodologique, les relations qui existent entre les mécanismes qui se mettent en place au cours des nombreuses offres à la consommation par la télévision et ceux enclenchés dans les phases de lectures, interprétations, appropriations et consommations effectives par les récepteurs.

Mots-clé : Réception; Télévision; Genre

\section{Apresentação}

Existem programas de TV diários nos quais os profissionais da saúde respondem a consultas dos telespectadores. Em geral, estes programas utilizam a participação do público, em diversos graus e modalidades. Em alguns deles, a participação é à viva voz, pelo telefone, ao vivo. Em outros, a audiência envia perguntas que os apresentadores lêem; há casos em que quem faz as perguntas é o próprio apresentador. Contudo, em todas as modalidades, há um convite ao público a implicar-se, ativamente, mediante o telefone, fax ou e-mail, estabelecendo-se um intercâmbio entre expertos e leigos, entre um 'dentro' da tela e um 'fora' da tela, conduzido no estúdio por um apresentador. É o caso das seções de dois programas que aqui analisamos: um, de alcance nacional, o Note e Anote (Rede Record) e outro, local, o Conversa Franca (Band-Bahia), os quais denominamos 'tele-consultas médicas'.

Nesses dois programas de televisão, mediante diversas estratégias, estabelecem-se relações com o público (trata-se de consultas médicas gratuitas), validam-se e instituem-se saberes sobre a saúde reprodutiva e propõem-se, implicitamente, relações de gênero e imaginários sociais sobre a saúde e sobre os conhecimentos científicos legitimados por e através desse suporte.

Propusemo-nos, especificamente, analisar as representações sociais articuladas pelos dois programas sobre o processo saúde/doença/cuidados da saúde reprodutiva das mulheres, focalizando especialmente o ciclo menstrual e seus transtornos para, depois, analisar e comparar as estratégias discursivas propostas pelas emissões com as estratégias de consumo, recepção e usos dos programas, realizados por um setor da audiência. Todo isso para refletir e analisar como, teórica e metodologicamente, se estabelecem vínculos entre as múltiplas ofertas de consumo elaboradas pelas instâncias de produção televisiva e 
as leituras, interpretações, apropriações e consumos efetivamente realizados pelos receptores.

\section{Os contratos de leitura e a recepção}

Tomando distância de perspectivas condutivistas, evidentemente, não se acredita aqui que as emissões de TV operam como estímulos que provocarão uma resposta (condutual ou psicológica), mas que a única forma possível de estudar experimentalmente a recepção - enquanto produção de sentidos fortemente orientada pela hegemonia midiática, e sem a ressonância social desta - é a partir da elaboração de hipótese sobre algum 'efeito de sentido’ provocado pelos textos-programas. Contudo, não podemos reduzir a recepção a um único processo nem a um único aspecto, o discursivo. Recepção é uma palavra extremamente polissêmica que inclui processos conscientes e lógicos de atenção, leitura, inferência, interpretação, compreensão/ não compreensão, exposição; processos inconscientes da ordem da adesão ou do desejo, e processos valorativos como a aceitação/rejeição, a acordo/discordância, o gosto/desgosto, dentre muitos outros. Todas as combinações entre esses termos são possíveis. Ainda, é preciso reparar na relativa autonomia das fases de emissão e recepção: nem sempre a recepção de um programa tem a ver com as estratégias discursivas deste, por isso a necessidade de um trabalho de interpretação etnográfica das condições de recepção, não discursivas (familiares, sociais, culturais, etc.). Ambas as metodologias se nos apresentaram como necessárias e complementares na medida em que um texto pode ser lido diferentemente, em diferentes contextos, e um mesmo contexto pode dar lugar a diversas leituras.

De um modo mais preciso, a questão central enfrentada na nossa pesquisa diz respeito à discussão do modo como um grupo pequeno de famílias de classe média baixa, setores excluídos, na terminologia sócio-política, que têm acesso limitado aos bens de saúde e aos bens culturais, assimilam, rejeitam, ordenam, categorizam, hierarquizam, enfim, reelaboram a oferta discursiva de medicina e saúde da televisão, levando-se em conta, também, alguns aspectos sócio-culturais e econômicos. A interpretação do pesquisador provém da costura e da interpretação do conjunto da produção discursiva das informantes, na procura dos repertórios regulares de conteúdo e de enunciação nos seus depoimentos, mas também de outras pistas interxtextuais, e das observações etnográficas.

A perspectiva metodológica empregada para analisar a recepção dos programas devia dar conta, em primeiro lugar, da irredutível unilateralidade da enunciação televisiva amenizada, como vimos, pela participação dos telespectadores - e do poder significante que, 
a priori, detém a mídia concentrada. Não se trata de analisar discursos que só circulam, mas que se renovam periodicamente em forma de ofertas quantitativamente limitadas (estamos falando de TV aberta), as quais o público, a princípio, assiste ou não, e quando o faz - como acontece com nossos entrevistados - , responde de muitas maneiras. O problema é como se colocam os públicos perante essas propostas e de que forma suas leituras vão avaliar os papéis sugeridos para cada um dos personagens.

As tele-consultas médicas foram submetidas a dois tipos de análise: dos aspectos temáticos e do discurso (dos contratos de leitura propostos). Através do primeiro, destrinchamos as conseqüências ideológicas e políticas das representações patriarcais da saúde telemediada, enfocando a desvalorização da menstruação e da tensão pré-menstrual, predominantes na cultura e na TV. Através da análise do contrato de leitura das emissões, tentamos entender os vínculos entre gêneros textuais e relações de gênero, e os modos de construção textual (imagens, sons, cenários, linguagem e aspectos espaciais e gestuais) em que esses valores tomam forma, o que nos permitiu propor hipóteses sobre os diferentes mecanismos de interpelação do público propostos por cada programa. Por isso, nos interessou, em primeiro lugar, analisar os produtos à luz do seu 'contrato de leitura' (Verón, 1985, 1983, 1988), o qual foi colocado à prova para testar as formas e modalidades que adquire a interpelação desses programas de tele-consultas médicas.

Para Verón, a relação entre um meio e seus leitores repousa sobre um pacto de leitura, elaborado pela instância da emissão, que vai ter êxito (vai ser cumprido, isto é, o suporte será lido, visto e ouvido) a depender das expectativas, motivações e interesses do público, mas, fundamentalmente, pelo funcionamento da enunciação, isto é, além dos conteúdos (enunciados) pelas modalidades do dizer (enunciação). O contrato está constituído pelo conjunto de regras e estruturas enunciativas estabelecidas pelo emissor, na sua produção discursiva, a partir da interação com um pretendido receptor. Assim, detectamos dois tipos de 'contratos de leitura', um em cada programa; isto é, duas formas através das quais programas cujo conteúdo é similar oferecem especificidades para concorrer no universo massivo das audiências de televisão. Para realizar a análise, do programa Note e Anote foram selecionados quatro programas (NOTE E ANOTE, 2002). Do Conversa Franca, foram selecionados cinco programas (CONVERSA FRANCA, 2002), quando se passava na TVBand-Bahia. Trata-se de uma amostra intencional, baseada em critérios de recorrência e de invariabilidade dos temas.

Nossas hipóteses sobre o contrato proposto ao público foram 'testadas' mediante uma análise interpretativa na fase da recepção, através de um 'estudo de caso', no qual analisamos os modos pelos quais as audiências se fazem cargo ou não das ofertas 
interpretativas dos programas, isto é, das instruções propostas pela emissão. Realizamos um trabalho etnográfico com um grupo de mulheres, todas elas vizinhas e telespectadoras mais ou menos regulares das emissões estudadas, moradoras num bairro popular da cidade de Salvador, o Engenho Velho de Brotas. Realizamos observações, entrevistas e focus groups e participamos de algumas atividades religiosas e comunitárias. Procuramos metodologias que nos permitissem uma produção abundante e suficientemente espontânea de depoimentos em contextos similares àqueles em que o consumo de tevê se dá na vida dessas pessoas, em família e em casa, assumindo a inevitável artificialidade da situação de inquérito. Os depoimentos foram recolhidos através de entrevistas semi-dirigidas e grupos focais. As entrevistas, que eram realizadas nas casas das informantes, foram longas conversas descontraídas que versavam sobre dois eixos, a televisão, seu consumo, recepção e usos, enfatizando os programas pesquisados, e a saúde reprodutiva, enfatizando-se a menstruação e seus transtornos, práticas de saúde, imaginários e saberes individuais, familiares e sociais. Realizaram-se 15 entrevistas gravadas (de quase uma hora cada uma), numerosas visitas e conversas informais durante os meses que durou nosso trabalho de campo. Os grupos focais eram compostos por 4 ou 5 membros e se reuniam nos domicílios das informantes.

Assumimos este trabalho procurando articular audiências, meios e textos televisivos. Procuramos encontrar, nas vozes do público dos programas de televisão, os traços enunciativos dos diversos lugares a partir dos quais se definem, ainda que provisoriamente, o corpo, a doença, a saúde, a própria identidade, e o lugar que a televisão ocupa na vida das pessoas e o quanto contribui na criação e reprodução dessas representações; tentamos entender os tipos de relações que, a partir das emissões, se estabelecem entre saberes de diferente hierarquia, possibilitando que certas coisas possam ser ditas, de uma forma específica, e que outras coisas não tenham chances de serem pronunciadas ou ainda, pensadas, na vida social.

\section{O gênero sexual no gênero textual (e vice-versa)}

O Note e Anote e o Conversa Franca apresentam estratégias de comunicação bem diferentes e, quando olhamos com maior detalhe, essas diferenças estão mais determinadas pelas restrições genéricas dos programas dos quais as tele-consultas fazem parte (trata-se de tele-consultas em um programa magazine, no caso do Note e Anote e de um jornalístico, no Conversa Franca) que dos recursos econômicos e técnicos - absolutamente desiguais - postos em jogo. Observamos que ambas propostas são esteticamente conservadoras enquanto recursos imagéticos utilizados, predominando o velho e econômico recurso das 'cabeças 
falantes', umas (no Conversa Franca) sobre um pano de fundo único e mínimos recursos técnicos - trata-se de um programa local sem grandes recursos financeiros; outras, (no Note e Anote), com maior dinamicidade, mais jogos de câmara e cenários apenas mais diversificados - trata-se de um programa transmitido numa rede nacional que fatura alto em merchandising.

Essas diferentes estratégias têm a ver com os gêneros nos quais estes subprodutos se encaixam, gêneros em sentido textual (genre) enquanto formas de organizar textos midiáticos, que compreendem tanto temáticas, modos de se dirigir ao público, como elementos contextuais, tais como horários, extensão, todas elas características permanentes, constantes, que asseguram a satisfação das expectativas do público a respeito da sua inteligibilidade e reconhecimento. Observamos que o gênero (genre) de ambos programas (magazine num caso e jornalístico em outro), mais do que expressar uma vontade de atingir um público determinado sexualmente, elabora o gênero (gender) dos telespectadores, mediante estratégias de feminilização ou masculinização embutidas tanto nos textos como nos contextos dos programas. Essas estratégias estão nos nomes dos programas, nas formas de se dirigir ao público (as formas socialmente consideradas "femininas" ou "masculinas"), nas temáticas (que supõem e propõem gostos diferenciados por sexos); nos horários (que supõem a presença/ausência de certos membros do lar). Assim, o Conversa Franca, programa jornalístico, oferta para homens e mulheres, pretende-se isento de relações de gênero (isto é, porque o masculino pretende-se norma e o feminino é a diferença) enquanto o Note e Anote feminiliza sua audiência. Essas formas genéricas dos programas propõem, prescrevem e definem as formas culturais da identidade sexual.

Sendo ambos os programas praticamente idênticos quanto às temáticas, abordagens e ideologias médicas colocadas em jogo, cada tele-consulta constrói um produto diferente devido ao tratamento enunciativo que se dá a esses temas (apesar de que estabelecem, os dois programas, um contrato de base pedagógico). Esse tratamento tem a ver com os artifícios discursivos, que incluem estratégias da ordem do lingüístico, do icônico, do gestual, do espacial e do sonoro. No programa local se constrói um vínculo cujo sustento radica na 'objetividade' da ciência e a impessoalidade do cientista, que ocupa o lugar tradicional e formal reservado ao saber científico, solicitando telespectadores independentes, distantes e relativamente informados, enquanto, no programa nacional, fica em relevo um contrato baseado na confiança e no afeto, um vínculo com umas telespectadoras de carne e osso, pouco informadas, carentes de conselhos médicos, contrato sustentado na 'objetividade da ciência' e na subjetividade do cientista. 
Nossas hipóteses afirmam (e o trabalho em campo, o confirma) que essas modalidades de comunicação são as responsáveis por arregimentar determinados públicos (os visados pela produção como potenciais e desejáveis públicos-consumidores) e orientar a recepção, no sentido de, uma vez capturados, orientar as interpretações, leituras e usos do público.

Essas modalidades diferenciadas, esses contratos de leitura, implicam toda uma aparelhagem técnica e discursiva que entra em jogo neste processo, em produção. Essas estratégias são, em geral, cuidadosamente planejadas, especialmente no Note e Anote, onde se jogam altíssimas quantias em publicidade, produção e salário da apresentadora. Já no caso do programa local, nem sempre as decisões dependem de opções estratégicas da produção, mas de táticas de sobrevivência 'no ar' que se sustentam ao redor da figura de alcance nacional que o médico representa. Não se trata de sopesar aqui quão intencionais e planejadas sejam as formas mediante as quais os programas se oferecem à disposição do público. O que nos importa, em produção, é interpretar quanto as lógicas econômicas, ideológicas, culturais e sociais estão marcadas no programa, são parte do texto-programa, para, em recepção, tentar saber quais efeitos de sentido são capazes de provocar essas configurações midiáticas, qual a capacidade de implicação que os públicos podem ter a partir dessa oferta, quão metabolizadas são as propostas dessas emissões.

No ápice do trabalho partimos, então, para a procura de leitoras cúmplices com o papel de pacientes ávidas de saber e necessitadas de conselhos médicos, como o programa Note e Anote deseja, e de leitoras interessadas em obter informação imparcial e científica, como o imagina o Conversa Franca. Encontramos muitas outras coisas, como era de se supor. Da análise da recepção dos contratos de leitura de ambos os programas pudemos ver algumas pistas para entender as diferentes estratégias de comunicação e o êxito diferente de cada uma das propostas. Entendemos a recepção de programas sobre saúde feminina como um dos momentos e locais do processo social de construção das ideologias medicalizantes e normalizantes do corpo feminino, mas não o único nem o principal, como pode ser percebido nas entrevistas realizadas. A recepção de tevê parece uma prática global; enquanto se assiste programa a programa com mais ou menos atenção, o que se captura em recepção é um resíduo significante da programação geral, dos temas, dos 'modos de dizer', produto da credibilidade geral da mídia e da confiança na sua permanência.

O êxito relativo encontrado nas informantes, que se adaptaram em quase todos os casos aos contratos propostos, demonstra que a dimensão referencial, predominante nos discursos de base científica, é a parte menos importante quando se fala de saúde tele- 
mediada. Isto tem conseqüências importantes tanto para a saúde quanto para os estudos de recepção.

Tanto nossos tele-médicos quanto a medicina fora da tela supõem que o que as pessoas fazem com sua saúde é produto de uma atividade consciente e intencional, que é possível de ser mudada através de um outro conhecimento ou informação. Acredita-se que o conhecimento sobre a saúde seja a resultante de um conjunto coerente de mensagens que, oferecidas aos sujeitos, passam a ser, em forma parcial ou incompleta, parte do estoque de pensamento disponível para a reflexão e a ação. Observamos, contudo, atitudes bem diferentes nos públicos pesquisados.

O médico paulistano, simpático e amável, assim como o sarcástico cientista baiano, provocaram nas suas telespectadoras (pelo menos, as entrevistadas por nós) juízos morais e estéticos, mas, por outro lado, em pouquíssimas ocasiões elas elaboraram juízos críticos em termos referenciais e ideológicos. Não se pronunciaram sobre a validade e pertinência das temáticas nem sobre as regras que regulam a narrativa do programa. Como uma espécie de revolta contra o logos da ciência, nossas telespectadoras não se opõem ao médico baiano, que as desgostou tanto, em termos conceituais ou ideológicos, e sim em termos estéticos. Em verdade, elas parecem completar, na recepção, a fragmentação e racionalização dos corpos oferecidos nas duas emissões. As diferenças historicamente determinadas entre os gêneros são as que permitiram colocar nossas entrevistadas - não sem contradições - no lugar de pacientes sensíveis a um sorriso, cujo sofrimento - corpos dóceis, enfim - forma parte do seu "ser mulher".

Essa objetivação do corpo, presente nas duas propostas, é muito mais marcante nas formas de expressão do médico baiano que nas modalizações do paulistano, para quem, além de um 'você', há um 'aqui e agora' para as tele-pacientes. As marcas de subjetividade notadas no programa Note e Anote são a razão de ser não da medicina, mas da televisão, esse lugar que é como nossa casa. Daí o êxito da proposta entre nossas entrevistadas.

Parece que, em recepção, o juízo crítico que se faz dos programas, globalmente, não parece impedir a existência de certa influência, mas o problema é caracterizá-la. Notamos forte influência de tipo cognitiva, agenciadora de temas, manifestada no vocabulário utilizado para referir-se ao corpo, a suas dores, às explicações das experiências corporais e sociais, como no caso da tensão pré-menstrual. A tensão pré-menstrual (TPM) nos chamou muito a atenção por tratar-se de um fenômeno discursivo de peso na comunidade interpretativa nacional, adepta ao uso de siglas a partir de uma prática jornalística já ritualizada. A TPM parece demonstrar a simbiose entre o texto da telespectadora e o corpo do texto midiático como espaço cultural (NIGHTINGALE, 1999). O corpo da telespectadora 
é um espaço cultural que produz signos de uma história pessoal, na qual a tevê está escrita/inscrita no corpo, de diversas formas.

A leitura dos textos televisivos pesquisados é individual e solitária, mas isto não significa que sua recepção não seja social. Trata-se de uma experiência pessoal que tem como marco a subjetividade, especialmente a história familiar, os relatos maternos, mas adquire sentido na medida em que se entrelaça com um coletivo social, o das 'vizinhas' ou 'amigas', que, no caso da saúde, partilham uma experiência socialmente contraditória que, por um lado, as valoriza por seu caráter fortemente emocional (especialmente, no que se refere à maternidade), e as vitimiza por sua medicalização e sua associação com o sofrimento. “A natureza é terrível com as mulheres” diz uma entrevistada, parafraseando o médico baiano. A permanente alusão à natureza feita pelos médicos adquire ressonância nas falas das mulheres. A natureza é tudo aquilo que elas não podem driblar, dominar ou controlar, mas a natureza é mãe e, portanto, é sagrada. Os repertórios que falam da identidade entre natureza e mulher são permanentes e inquestionáveis.

Todas as telespectadoras entrevistadas têm tendência a utilizar repertórios interpretativos baseados em julgamentos morais ('ruim/bom', ‘contra/a favor’; 'limpo/sujo') e relações de poder ('deve/não deve'; 'pode/não pode'; 'acho/não acho', este último em forma reiterada) formuladas sempre em termos binários, assim como se detectou o uso freqüente de certas palavras provenientes dos âmbitos exotéricos da ciência mediatizada, que funcionam como imagens, construções de mundo inverificáveis mas irrefutáveis, expressadas por palavras ou frases sintéticas, tais como 'hormônios', 'reposição hormonal', 'cientista', 'glândulas', 'limpar o útero', 'cisto', 'sangue sujo/bom', algum deles, utilizados constantemente pelos médicos. Esse tipo de depoimento parece fruto do "efeito agenda" da mídia; não temos certeza se a televisão diz a essas mulheres como pensar, mas parece ter uma capacidade espantosa para lhes indicar sobre o que pensar em termos de saúde reprodutiva, e com que repertório lingüístico, o que convida a refletir sobre que relações de poder estão se cristalizando nessas expressões.

As recomendações de beber chá, por parte dos médicos, as reconcilia com a prática médica e quanto mais o médico se aproxima da cultura vivida, mais é valorado, porque a ciência ameaça os aspectos emocionais dos seus saberes. Respeita-se muito o saber científico-midiático, mas valora-se ainda mais na medida em que vai ao encontro de saberes familiares e comunitários arraigados, mesmo que socialmente desvalorizados. A medicina é mais do que um conjunto de técnicas usadas perante uma doença; é um conjunto de normas e valores acerca de si e do próprio corpo, das suas atividades e relações com o entorno, com as comidas, com o ambiente, com os outros, e quando entra em contato com outros 
conjuntos de valores e lógicas, é confrontada com esses saberes. A medicina pensa os cuidados como se fossem normas, estruturas racionais e voluntárias de conduta, enquanto elas pensam os cuidados da saúde como algo afetivo, algo para ser resguardado da erosão do discurso científico.

Há diferentes atitudes perante a oferta televisiva: há quem se posiciona criticamente, há quem negocia permanentemente. Alguma desconfia dos conteúdos, mas desconfia mais ainda da validade dos seus próprios conhecimentos. A interpretação dos programas de teleconsultas médicas se dá sobre o pano de fundo da própria experiência, na qual participam, sempre, outras mensagens, outras instituições, outras vozes. O trabalho da interpretação consiste no confronto entre saberes provenientes de outras fontes (familiares, pessoais, sociais) e as propostas das emissões, e esse confronto coloca em jogo o próprio corpo, as percepções que temos dele, a história familiar, pode reescrever a 'novela familiar', diria Freud.

Jamais qualquer das entrevistadas colocou em questão a pertinência, validade e autoridade dos médicos, das temáticas, dos suportes. O médico da televisão é o equivalente ao médico pessoal, mas aquele médico ao qual, pelas condições sócio-econômicas, elas não têm acesso; a tele-consulta, uma maneira barata e fácil de satisfazer a curiosidade ou tirar algumas dúvidas com um profissional cuja autoridade emana, basicamente, da sua popularidade midiática.

Em geral, todas parecem crer na legitimidade da tele-consulta e da televisão, e nos personagens recriados pelos dois médicos e os apresentadores. Essa credibilidade é fruto da experiência midiática, de uma série complexa de imagens que as receptoras têm da televisão, em geral, dos gêneros, da confiança depositada no meio, dos programas e dos personagens, fictícios e reais, e, também, da ciência médica. Contudo, a experiência do telespectador se constitui ao redor de uma pluralidade de programas de verdades e de regimes de crenças: pode-se crer sem crer, crer mais ou menos, ou crer em coisas contraditórias, pode-se saber e preferir crer em outra coisa, ou então fazer de conta que se crê. O que está claro é que há uma questão de credibilidade muito forte. Por isso o saber através da mídia virou um saber de 'primeira mão'; porque o 'vi na tevê’ vem a significar 'por que o vi’. Mas a crença na televisão não parece uma crença religiosa, ao contrário, é provisional, temporária, até o aparecimento de uma outra.

Podemos afirmar que praticamente todas cumprem à risca as exigências do contrato formulado pelo Note e Anote, cujas telespectadoras assumem-se fãs e cúmplices incondicionais do simpático médico paulistano. Já o Conversa Franca apresentou um leque de posições maiores, porém não muito divergentes. Algumas das informantes parecem as 
destinatárias imaginadas pelos produtores do programa baiano, algo infiéis (pois não assistem assiduamente), mas aceitam o contrato algo agressivo proposto pela emissão. Distantes, não se deixam seduzir facilmente, mas entram na polêmica proposta pelo médico. Não expressam dúvidas quanto ao conteúdo do falado nem ao lugar de fala dos enunciadores, mas coloca-se em questão o próprio lugar ativado pela emissão, o ego.

"Ele aí e eu aqui" parece ser uma boa metáfora para equacionar a convivência entre dois espaços temporal e espacialmente distantes, que entram em confluência na tela, mas que podem lidar com eles na medida em que se consegue preservar o próprio lugar. Se as formas que adquirem as atividades midiáticas em recepção falam de estilos de vida e das relações interpessoais, dos ambientes emocionais e das relações comunicativas no seio das famílias, provavelmente estes depoimentos podem ser interpretados como projeções de um desejo de autonomia sem confronto, sem conflitos.

Do mesmo modo, frente aos trechos do Note e Anote, todas se colocam sem reservas no lugar de pacientes curiosas, necessitadas de informação, de telespectadoras aplicadas e atentas, espectadoras idealizadas pelos programadores da Record. Muitas informantes resgatam os aspectos emocionais do vínculo que o médico estabelece com seu público. Ele parece 'humano' e a imagem que todas têm da medicina é a de desumanização. Interessante destacar como, apesar da dominante referencial ou de conteúdo do programa, - trata-se de conselhos médicos, de dicas, de sugestões e de ordens - percebe-se que a forma prevalece sobre os conteúdos. O apelo emocional é fundamental, por isso a performance do Dr. Bento as fascina, o drama as cativa. As telespectadoras são capturadas, em recepção, pelo show do médico, pela dimensão do contato, fundamental na televisão.

Parecem, todas elas, fazer parte de uma comunidade interpretativa básica, onde se dão algumas diferenças internas, produto da educação e da história familiar. As categorias mais determinantes para analisar os usos e controle sobre a programação parecem ser o gênero e a geração. A mais determinante para analisar os repertórios usados para falar da saúde reprodutiva, parece o gênero, pelo menos quanto à reprodução acrítica de repertórios patriarcais sobre o corpo reprodutivo.

\section{Conclusões}

A importância e magnitude sociológica e política que se desprendem das numerosas pesquisas sócio-econômicas sobre a televisão, quando olhado o fenômeno para os contextos 'micro' da vida cotidiana, parecem diluir-se, esfumar-se, fundir-se na insignificante rotina diária. Onde reside esse poder? Parece nômade, cigano, sem domicílio, ou então, nunca 
estava quando tocamos a campainha nessas casas que entrevistamos. A aparente insignificância política das práticas midiáticas nos fez entrar em crise durante vários momentos, especialmente na hora de ler os longínquos depoimentos transcritos e as detalhadas observações de campo, nunca o suficientemente detalhadas o quanto é recomendado para um bom diário de campo. Perante as horas e horas de fitas gravadas e transcritas, nos angustiamos quando líamos infinitas e monótonas descrições da vida diária das entrevistadas, em busca de alguma pista que fugisse do previsível, do que 'é esperável', em procura do original, ou então do pitoresco, do único, daquilo que justificasse tamanho esforço. Se qualquer explicação causal ou determinista sobre a influência da televisão nos está terminantemente proibida, se desde Morley (1999) e Hall (1996) o texto caiu do trono, já não é o dono do significado e do poder, é porque o poder está em todas partes (Foucault já o disse faz décadas) e havia que sair em sua busca para lhe dar corpo, reconstituí-lo desde sua aparente irracionalidade, sua naturalidade e sua relativa estabilidade, isto é, desde tudo aquilo que define a vida cotidiana, e ao que tudo indica, o lugar da televisão é ali, no enigma do dia-a-dia.

Acontece que é um lugar arredio porque é autoevidente e a televisão é um objeto fugidio, de difícil apreensão. Entre outras coisas, porque em poucas ocasiões se assiste televisão atentamente, isto é, se assiste sentado frente ao televisor, olhando para a tela. Alguns pouquíssimos programas têm este tipo de audiência e sempre depende das circunstâncias: o telejornal do meio-dia, se se está na mesa, na hora do almoço. A novela das oito, se não se está cozinhando. O futebol parece ser uns dos poucos momentos de concentração frente à tela, pela natureza visual da emissão e o papel dos locutores, completamente diferente dos de rádio, e isto é valido para os homens, especialmente. Fora isso, o que está claro é que se assiste muito pouco 'para assistir' e menos ainda, 'para aprender' qualquer coisa relativa à saúde; os magazines, e as tele-consultas são vistas e ouvidas enquanto se faz qualquer coisa: ler revistas, crochê, trabalhar nos afazeres domésticos, ajudar as crianças nas tarefas de casa. O televisor pode ficar ligado durante horas, como pano de fundo, como um fluxo permanente. São poucos os programas que têm importância para serem assistidos com maior convicção e aproveitamento. Parece que o televisor funciona como um rádio, uma emissão permanente à qual se lhe presta uma atenção seletiva. Em verdade, trata-se de uma escuta.

O convite televisivo, o contrato de leitura - cumprido nos termos propostos pela emissão por quase todas as informantes - parece funcionar pessoa a pessoa, o que não significa que o público seja um conjunto atomizado de indivíduos nem que funcione por características puramente psicológicas. O contrato detecta-se no indivíduo, mas é possível 
que possam ser elaboradas tendências ou conjuntos homogêneos de leituras. E estas leituras não devem ser tomadas como expressão de determinações psicológicas; não se trata de um problema de personalidade e sim de identidades e performances, no sentido de papeis e posições assumidas pela e através da atividade enunciativa, em contextos determinados. Seria muito mais útil poder elaborar tendências semio-sociológicas mas para isso é preciso uma amostra maior e a combinação de metodologias.

Todos os pesquisadores de recepção temos diferentes audiências na cabeça, disse alguma vez Hall. Isso, porque continuamos a pensar nas audiências como coisas objetiváveis, ou melhor, coisificadas, como entidades fixas, como populações (vizinhos, cidadãos, nações) ou grupos (mulheres, homens, negros, crianças, classes), - assim como no início se pensava em 'massas' - e não como relações entre textos midiáticos e determinados públicos em tempos e contextos determinados. Isto é, a audiência (ou público) se cria na relação com um texto e essa relação está marcada por um contexto. A maior dificuldade está em capturar essa relação, que pode ser efêmera ou duradoura, pois nem sempre se é audiência o tempo todo, e como diz Orozco Gomez, (1991) a recepção é um processo e não um momento; pode continuar após desligarmos a TV.

Nesse sentido, uma pesquisa qualitativa e etnográfica baseada na análise do contrato de leitura de meios, captura uma das formas em que a audiência se forma em relação a um texto; objetiviza, fixa - temporária e circunstancialmente - a relação meios-textos-públicos (que de outra forma seria impossível de estudar) e, antes de tudo, relativiza a leitura do pesquisador, ao colocar as 'cláusulas' do contrato como hipóteses de leitura.

Expressar uma opinião, responder uma demanda da TV significa, além de expressar um conteúdo, oferecer uma imagem de si mesmo, significa emitir um juízo moral e social, e também, realizar uma performance, uma cerimônia comunicativa aprendida socialmente, através das quais as pessoas se relacionam. Entender as respostas das entrevistadas como performances não significa duvidar do que dizem, mas, ao contrário, são provas das atitudes que os sujeitos parecem dispostos a ocupar nos intercâmbios sociais. É politicamente decepcionante aceitar que nossas entrevistadas se adaptaram quase por completo ao pacto oferecido pela emissão, um pacto baseado na cumplicidade com uma medicina que atenta contra os pudores e sentimentos mais íntimos, que as reduz a meras pacientes, objetos de olhares que não vêem nada além de si próprios.

A sensação se relativiza quando se analisam os depoimentos em seu contexto e aparecem os silêncios, as reticências e os espaços em branco, as referências àquelas percepções que se aprimoram com afeto e fundamentalmente, a riqueza das vivências comunitárias que as vinculam solidariamente com o bairro. A idéia de 'voluntariado', de 
'sofrimento', da vida como 'passagem', realmente gera uma moral que impregna todas as práticas. Moral contraditória que inclui racismo e engajamento em lutas sociais amplas.

Praticamente não se detectaram repertórios interpretativos para fazer referências às condições de produção da emissão. Se se aprende pelo que se ouve e vê, também se aprende pelo que a mídia silencia; nesse sentido não houve questionamentos ao tipo de relações que se estabelecem entre os atores dos cuidados, nem às condições sociais, culturais e econômicas onde a saúde se dá.

O conceito de 'contrato de leitura', seu cumprimento ou não cumprimento, demonstra ser útil porque permite pensar o ideológico muito menos como mero conteúdo e mais como uma estrutura discursiva complexa nas quais se incluem e excluem posições de sujeitos, conteúdos, modalidades enunciativas, contextos micro e macro, frente ao qual o receptor poderá posicionar-se de várias maneiras, aceitar ou não um lugar proposto pela emissão. O conceito permite explorar efeitos de sentido mais amplos e difusos, elaborar hipóteses explicativas mais refinadas sobre a recepção. Por outro lado, o contrato é uma instrução de leitura, a emissão é considerada uma polissemia fortemente estruturada, mas para comprovar seu cumprimento se colocam em jogo dimensões de percepção (de si e do ambiente) e de sensibilidade.

Originalmente pensado para analisar meios gráficos, o conceito parece ser de interessante para compreender as dimensões subjetivas e sensíveis que envolvem certos públicos com certos programas de televisão, dimensões que são, sem dúvida alguma, tão ideológicas quanto os aspectos referenciais. Ainda, nos permite colocar a leitura (ou sua recusa) como uma relação de poder, como um exercício de poder (que não é outra coisa o que os meios fazem).

Nossas leituras das respostas dos telespectadores devem ser tomadas como pistas, algo assim como pegadas que indiquem caminhos a seguir, hipóteses sobre a relação entre os textos televisivos e seu campo de efeitos de sentido possíveis no plano da recepção, hipóteses construídas sobre um processo extremamente complexo, em que entram em jogo não só os textos analisados, mas uma polifonia de textos (midiáticos e não midiaticos), e sujeitos, pessoas de carne e osso, em contextos diferentes, que responderam, às vezes animadamente, e outras, por pura amabilidade, obrigação ou curiosidade, sobre uma temática sobre a qual jamais pensaram que merecia alguma reflexão específica e menos ainda, acadêmica, o consumo de tevê.

Observamos que quase todas as leituras relacionadas com aspectos proposicionais que fazem referências a práticas populares de saúde, enraizadas na cultura familiar, e desprezadas pela biomedicina televisada, criam lugares de conflito. Algumas definições são 
refutadas, contestadas, incomodam. Mas esse conflito não é visualizado como um problema de "poder" mas de "saber", o qual se contorna facilmente: "ele, ali e eu aqui”. "Deixa que fale”, ou então desligo o televisor, ou melhor, faço zapping (quando não tem ninguém em casa que me impeça). Demos umas voltas e chegamos ao ponto de partida, à insuportável leveza do poder da televisão. Em algum sentido e parafraseando Freud, a recepção (e sua análise) é impossível.

Isto dá conta de um tema fundamental marcado pelos Estudos Culturais em recepção, que é o do descentramento do texto, o de irmos do meio à cultura, mas sem apagar o texto, sem desligar a tevê. Nossa tentativa levou em conta esse nó, que acreditamos ser ainda um problema carente de profundos e reiterados esforços acadêmicos.

\section{Referências bibliográficas}

CONVERSA FRANCA. Programa de televisão gravado. São Paulo: Rede Bandeirantes. Edições incluídas: o9 dez. 1999, 15 dez. 1999, 22 dez. 1999, 26 jul. 2000, o9 ago. 2000. O1 Fita VHS. 2002.

HALL, Stuart. Cultural Studies and its theorethical legacies. In: MORLEY, David; CHEN, Kuan-Hsing (Orgs.). Stuart Hall: Critical dialogues in Cultural Studies. London-New York: Routledge, 1996. p. 262-275.

MORLEY, David; BRUNSDON, Charlotte;. The Nationwide Television Studies. London: Routledge, 1999.

NIGHTINGALE, Virginia. El estudio de las audiencias: El impacto de lo real. Barcelona: Paidós, 1999.

NOTE e ANOTE. Programa de televisão gravado. São Paulo: Rede Record. Edições incluídas: 25 jan. 2001, 06 dez. 2001; 14 mar. 2002, 25 jul. 2002. 01 Fita VHS, 2002.

OROZCO GOMEZ, Guillermo. La audiencia frente a la pantalla: Una exploración del proceso de recepción televisiva" . Diá-logos: de la comunicación n. 30, Cali, Felafacs, junho 1991. p.55-63.

VERÓN, E. Il est là, je le vois, il me parle. Revue Communications, Paris, Seuil, n. 38, 1983, p. 98-120.

VERÓN, Eliseo. L'analyse du contrat de lecture: une nouvelle methode pour les etudes de positionnement des supports presse. In: Les médias: expériences, recherches actuelles, applications. Paris, IREP, 1985

VERÓN, Eliseo Prensa escrita y teoria de los discursos sociales: producción, recepción, $\quad$ regulación. $\quad$ Dis p o nível l e m : $<$ http://www.biblioteca.org.ar/autort.asp?texto $=$ e\&tipo $=5>$. [Presse écrite et théorie des discours sociaux: production, réception, régulation. In CHARAUDEAU, P. (Comp.) La Presse. Produit, production, réception. Paris, Didier, 1988]. 